ISSN 1678-3921

Journal homepage: www.embrapa.br/pab

For manuscript submission and journal contents, access: www.scielo.br/pab

\section{Nonlinear equations to determine the growth curve of immunocastrated pigs}

\begin{abstract}
The objective of this work was to compare the performance of the nonlinear Gompertz, logistic, and von Bertalanffy equations, to describe the growth curve of immunocastrated male pigs from birth until reaching $140 \mathrm{~kg}$ body weight. Standard error, number of iterations, mean square of the error, and coefficient of determination were compared between the models. The logistic and von Bertalanffy equations do not accurately estimate the initial and slaughter weights. The Gompertz equation shows the highest reliability and is, therefore, the most suitable one to describe the growth curve of immunocastrated pigs from birth until $140 \mathrm{~kg}$ body weight is reached.
\end{abstract}

Index terms: Gompertz, growth rate, logistic equation, von Bertalanffy.

\section{Equações não lineares para determinar a curva de crescimento de suínos imunocastrados}

Resumo - O objetivo deste trabalho foi comparar o desempenho das equações não lineares de Gompertz, logística e a de von Bertalanffy, para descrever a curva de crescimento de suínos machos imunocastrados, desde o nascimento até atingirem $140 \mathrm{~kg}$ de massa corporal. O erro-padrão, o número de iterações, o quadrado médio do erro e o coeficiente de determinação foram comparados entre os modelos. A equação logística e a de von Bertalanffy não estimam com precisão as massas inicial e de abate. A equação de Gompertz apresenta maior confiabilidade e é, portanto, a mais adequada para descrever a curva de crescimento de suínos imunocastrados, desde o nascimento até a obtenção de140 kg de massa corporal.

Termos para indexação: Gompertz, taxa de crescimento, equação logística, von Bertalanffy.

Nonlinear equations have been used in animal production to study and interpret biological processes (for instance the animal growth), and to understand the population dynamics in the production environment. Growth curves show an exponential or sigmoidal pattern, and they are modeled by nonlinear equations (Nascimento et al., 2017).

The description of growth curves of animals over time is essential for the development of mathematical models to estimate the growth, as well as to determine nutritional requirements and the ideal moment for slaughter (Carabús et al., 2017; Remus et al., 2020). Growth curves are generated by relating the weights ("Y") and ages ("t") of the animals, using nonlinear equations (Fernandes et al., 2019). Equations used to describe animal growth include the Gompertz, logistic, and von Bertalanffy equations (Iglesias et al., 2014). The number of parameters, 
ease of measurement, and estimation precision are the criteria used to determine the equation to estimate animal growth (Kyriazakis \& Whittemore, 2006).

New technologies such as immunocastration modify the growthrate ofanimals and, consequently, theirgrowth pattern (Carabús et al., 2017). Immunocastration involves the intramuscular application of the gonadotropinreleasing hormone $(\mathrm{GnRH})$. This analogue is recognized by the organism, which then starts to fight it, as an antigen. Since the analogous compound to $\mathrm{GnRH}$ does not have receptors to complete the connection with the hypophysis, it blocks the testosterone production by the animal (Kress et al., 2019). However, there have been no studies indicating the best equation for describing the growth of immunocastrated male pigs (Sus scrofa domesticus L.).

The objective of this work was to compare the performance of nonlinear Gompertz, logistic, and von Bertalanffy equations, to describe the growth curve of immunocastrated pigs from the birth until reaching 140 $\mathrm{kg}$ body weight.

The protocols used were approved by the Animal Ethics Committee of Universidade Federal de Santa Maria (UFSM, protocol number 8688070716). The experiment was divided into three stages: lactation phase, nursery phase, and growing-finishing phase. Sixty male piglets (Agroceres $\mathrm{x}$ Danbred) were monitored during the lactation phase, with $1.422 \pm 0.600$ $\mathrm{kg}$ initial mean body weight. In this period, the animals were individually weighed, weekly, until 28 days of age.

In the nursery (from 29 to 69 days of age) and growing-finishing phase (from 70 days of age to the age of slaughter, 174 days), the pigs were housed in five stalls with capacity for 12 animals each. The bays were equipped with the feeding station FIRE (feed intake recording equipment) and two drinking nipples. During this period, the animals were subjected to a diet program of four ad libitum diets, formulated according to the nutritional requirements of the NRC (2012), as follows: initial phase 1 (I1, 6 to $9 \mathrm{~kg}$ ), 3,400 $\mathrm{kcal} \mathrm{kg}^{-1}$ of metabolizable energy (ME), and $1.58 \%$ of digestible lysine (DL); initial phase 2 (I2, 9 to $15 \mathrm{~kg}$ ), 3,375 kcal kg-1 ME, and $1.33 \%$ DL; initial phase 3 (I3, 15 to $30 \mathrm{~kg}$ ), $230 \mathrm{kcal} \mathrm{kg}^{-1} \mathrm{ME}$, and 1.01\% DL. During the growth and termination phases, the following diets were administered: growth phase $1(\mathrm{Cl}, 24$ to $50 \mathrm{~kg})$, $3,250 \mathrm{kcal} \mathrm{kg}^{-1} \mathrm{ME}$, and $1.09 \% \mathrm{DL}$; growth phase 2 (C2, 51 to $70 \mathrm{~kg}$ ), 3,250 kcal kg-1 ME, and $1.01 \% \mathrm{DL}$; termination phase 1 ( $\mathrm{T} 1,71$ to $100 \mathrm{~kg}), 3,250 \mathrm{kcal} \mathrm{kg}^{-1}$ $\mathrm{ME}$, and $0.81 \% \mathrm{DL}$; and termination phase 2 (T2, 101 to $140 \mathrm{~kg}$ ), 3,100 $\mathrm{kcal} \mathrm{kg}^{-1} \mathrm{ME}$, and $0.75 \% \mathrm{DL}$.

In the growing-finishing phase, the animals were weighed individually in real time by the feeding station FIRE, and they were immunocastrated according to the vaccination protocol of the product manufacturer. The first and second doses of Vivax $(200 \mu \mathrm{g}$ GnRHProtein $\mathrm{mL}^{-1}$ ).(Zoetis, São Paulo, SP, Brazil) were subcutaneously applied $(2 \mathrm{~mL})$ in animals at 16 and 23 weeks of age, respectively.

The nonlinear Gompertz, logistic, and von Bertalanffy models were fitted to the weight-age data of the pigs via nonlinear regression, using the Minitab statistical program (McKenzie \& Goldman, 2010). The growth rate and inflection point in relation to the body weight and age of the animals were calculated according to the equations (Table 1). The mean squared error (MSE), coefficient of determination $\left(\mathrm{R}^{2}\right)$, standard error (S), number of iterations, and the biological interpretation of the parameters were analyzed for each equation, to determine which one was the most appropriate for estimating the body growth of the pigs.

When comparing the estimates of weight at maturity, or asymptotic weight ("A"), obtained by the different nonlinear equations for body weight (BW) of immunocastrated pigs, the logistic equation ( $\log E)$ showed a lower-A value (169.0 kg per BW) than the Gompertz equation (gpzE, $255.7 \mathrm{~kg}$ per BW) and von Bertalanffy (berE, $398.8 \mathrm{~kg}$ per BW) equations (Table 1). It has been previously reported that $\log E$ estimates lower weights at maturity, ranging from 99.9 to $149.0 \mathrm{~kg}$ per $\mathrm{BW}$, while berE generally estimates high-A values for pigs, ranging from 243.0 to 329.0 kg per BW (Freitas, 2005; Fernandes et al., 2019). However, gpzE frequently estimates more realistic values of A, ranging from 222.7 to $259.5 \mathrm{~kg}$ per BW (Freitas, 2005; Casas et al., 2010; Coyne et al., 2015; Luo et al., 2015).

The parameter B in the logistic and von Bertalanffy equations represents the degree of maturity of the animal at birth. High values of B represent low degrees of maturity at birth. According to Freitas (2005), the parameter B has no biological interpretation, but it is important to model the sigmoidal curve from birth $(t=0)$ until adulthood $(\mathrm{t} \rightarrow \infty)$. The parameter $\mathrm{K}$ indicates the animal growth rate, and determines the growth rate 
up to the asymptotic weight, from the animal's initial weight. Thus, the higher the value of $\mathrm{K}$, the faster the animal will approach its weight at maturity.

Out of the three nonlinear equations evaluated, $\log E$ showed the highest value of $\mathrm{K}(0.027 \mathrm{~kg}$ per day). Higher values of $\mathrm{K}$ concentrate growth around the inflection point, increase the maximum growth rate, and reduce the weight at maturity estimated by the growth curve. And smaller values of $\mathrm{K}$, as estimated by berE ( $0.006 \mathrm{~kg}$ per day) indicate that growth is more distributed over time, increasing the estimated asymptotic weight. The growth rates estimated by gpzE and berE were similar to those determined by Carabús et al. (2017), who used the Gompertz equation (0.012 kg per day), and Kebreab et al. (2007), who used the von Bertalanffy equation ( $0.006 \mathrm{~kg}$ per day).

When $\mathrm{A}$ and $\mathrm{K}$ were evaluated, it was possible to observe that the asymptotic weight, and that there was a decrease of the maturity rate. This antagonistic behavior has been reported by other authors (Freitas, 2005; Coyne et al., 2015).

In general, all equations showed a good fit to the data. However, gpzE and berE showed the highest values of $\mathrm{R}^{2}$ and the smallest number of iteractions, which resulted in more accurate estimates of the animal BW, as also observed by Luo et al. (2015) and Fernandes et al. (2019).

The evaluation of growth curves for the observed weights and age-predicted weights, based on the parameters estimated by the nonlinear equations. Figure 1, showed that gpzE gave the best estimate of the weights of the animals, in relation to the weights observed during their lives; $\log \mathrm{E}$ overestimated the

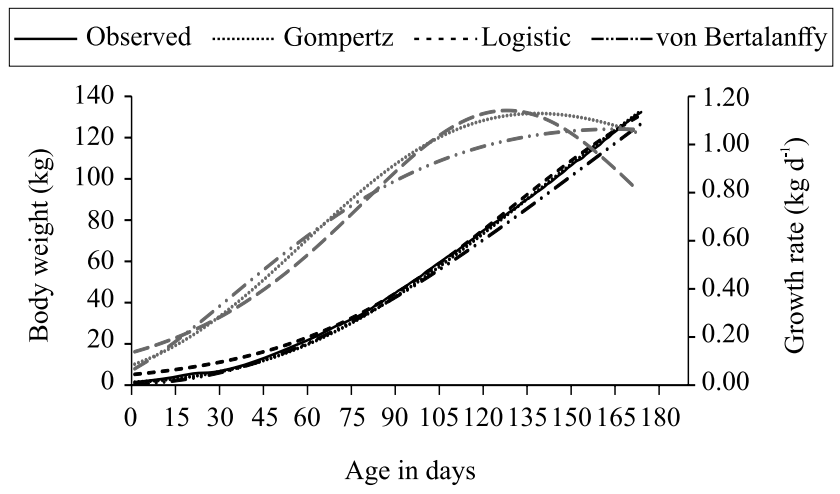

Figure 1. Mean of observed weights, predicted weights by age (black lines), and growth rates (gray lines), estimated by derivatives of Gompertz, logistic, and von Bertalanffy equations of immunocastrated pigs, from birth until $140 \mathrm{~kg}$ body weight was reached (age of slaughter, 174 days).

Table 1. Parameterization of the nonlinear equations to estimate the growth curve of immunocastrated male piglets (Sus scrofa domesticus) (Agroceres x Danbred) from birth until $140 \mathrm{~kg}$ body weight.

\begin{tabular}{|c|c|c|c|}
\hline Model & Equations & Weight IP & Age IP \\
\hline Gompertz & $\mathrm{Y}=\mathrm{A} * \exp (-\exp (-\mathrm{K} *(\mathrm{t}-\mathrm{C})))$ & $=\mathrm{A} / \mathrm{e}$ & $=\mathrm{C}$ \\
\hline Logistic & $\mathrm{Y}=\mathrm{A} /(1+\mathrm{B} \exp -\mathrm{K} * \mathrm{t})$ & $=\mathrm{A} / 2$ & $=(\ln (\mathrm{B})) / \mathrm{K}$ \\
\hline \multirow[t]{2}{*}{ von Bertalanffy } & $\mathrm{Y}=\mathrm{A}^{*}\left(1-\mathrm{B} \exp -\mathrm{K}^{*} \mathrm{t}\right)^{\wedge} 3$ & $=(8 * \mathrm{~A}) / 27$ & $=\log (\mathrm{e}) *(3 * \mathrm{~B}) / \mathrm{K}$ \\
\hline & \multicolumn{3}{|c|}{ Growth rate of nonlinear equations (first derivative) } \\
\hline Gompertz & \multicolumn{3}{|c|}{$\mathrm{Y}=\mathrm{A} * \mathrm{~K}^{*} \exp \left(-\mathrm{K} *(\mathrm{t}-\mathrm{C})-\exp \left(-\mathrm{K}^{*}(\mathrm{t}-\mathrm{C})\right)\right)$} \\
\hline Logistic & \multicolumn{3}{|c|}{$\mathrm{Y}=(\mathrm{A} * \mathrm{~B} * \mathrm{~K} * \exp (\mathrm{K} * \mathrm{t})) /\left((\mathrm{B}+\exp (\mathrm{K} * \mathrm{t}))^{\wedge} 2\right)$} \\
\hline von Bertalanffy & \multicolumn{3}{|c|}{$\mathrm{Y}=3 * \mathrm{~A} * \mathrm{~B} * \mathrm{~K}^{*} \exp (-3 * \mathrm{~K} * \mathrm{t}) *\left(\mathrm{~B}-\exp \left(\mathrm{K}^{*} \mathrm{t}\right)\right)^{\wedge} 2$} \\
\hline Parameters & Gompertz & Logistic & von Bertalanffy \\
\hline $\mathrm{A}(\mathrm{kg}$ per $\mathrm{BW})$ & 255.7 & 169.0 & 398.8 \\
\hline B & - & 31.747 & 0.902 \\
\hline $\mathrm{K}$ (kg per day) & 0.012 & 0.027 & 0.006 \\
\hline $\mathrm{C}$ (day) & 138.4 & - & - \\
\hline Weight IP ( $\mathrm{kg}$ per BW) & 94.09 & 84.52 & 118.1 \\
\hline Age IP (days) & 138 & 128 & 196 \\
\hline Iterations & 5 & 6 & 5 \\
\hline MSE & 68.8944 & 70.6139 & 68.9213 \\
\hline S & 8.30027 & 8.40321 & 8.30189 \\
\hline $\mathrm{R}^{2}$ & 0.9994 & 0.9977 & 0.9996 \\
\hline
\end{tabular}

IP, inflection point of the sigmoidal curve; e, base of the Neperian logarithm (e, 2.71828); Y, body weight at age t; A, weight at maturity; B, constant integration; $\mathrm{C}$, age at which the maximum growth rate is reached, which is the inflection point of the sigmoidal curve; K, growth rate; MSE, mean squared error; $\mathrm{S}$, standard error; $\mathrm{R}^{2}$, determination coefficient. 
BW from birth up to 42 days of age. Based on the estimates of the A and B parameters of $\log E$, the birth weight of the animals would be $5.229 \mathrm{~kg}$ per BW, a value considered physiologically unfeasible, as the mean birth weight predicted from the individual curve of the animals was $1.422 \mathrm{~kg}$ per BW. Luo et al. (2015) also observed that $\log E$ overestimated weights in the initial stage (birth to 50 days) of Liangshan pigs: the birth weight estimated by $\log \mathrm{E}$ of these animals was $4.130 \mathrm{~kg}$ per BW, and the real weight was $0.770 \mathrm{~kg}$ per BW.

The berE underestimated the birth weight and the weights from 110 to 174 days of age (slaughter). The weights at birth and slaughter estimated by berE were $0.982 \mathrm{~kg}$ and $5.522 \mathrm{~kg}$ lower than the observed mean birth weight ( $0.441 \mathrm{vs} 1.422 \mathrm{~kg}$ per BW) and slaughter weight (126.7 vs $132.3 \mathrm{~kg}$ per BW), respectively. Freitas (2005) used berE to describe the growth curve of Large White male pigs from birth to sexual maturity, and found that this equation underestimated the birth weight of these animals by $0.150 \mathrm{~kg}$. However, Luo et al. (2015) found that berE overestimated the slaughter weight of the animals by $0.420 \mathrm{~kg}$. The greater accuracy in the estimation of the slaughter weight observed in the present study may be a consequence of the greater number of weights recorded close to adult age (250 days of age), which increased the accuracy of the estimates of the growth curve (Kyriazakis \& Whittemore, 2006).

As berE showed the lowest-K value $(0.006 \mathrm{~kg}$ per day) of the three equations (Table 1), the age (196 days) and BW $(118.1 \mathrm{~kg})$ at the inflection point of the sigmoid curve (IP) were higher than that for gpzE (138 days and $94.09 \mathrm{~kg}$ per BW) and $\log \mathrm{E}$ (128 days and $84.52 \mathrm{~kg}$ per BW).

The Gompertz, logistic, and von Bertalanffy equations showed a good fit to the growth data of pigs. However, the logistic equation overestimated the birth weight, and the von Bertalanffy equation underestimated both the birth weight and slaughter weight of the animals. The Gompertz equation accurately estimated the initial and slaughter weights of the pigs, and its parameters $(\mathrm{A}, \mathrm{K}, \mathrm{C})$ have a biological significance. Therefore, the Gompertz equation shows the highest reliability and is the most suitable equation for describing the growth of immunocastrated pigs from birth until $140 \mathrm{~kg}$ body weight is reached.

\section{Acknowledgments}

To Conselho Nacional de Desenvolvimento Científico e Tecnológico $(\mathrm{CNPq})$, for granting a doctoral scholarship to the first author, and for funding this project (454577/2014-1); to Coordenação de Aperfeiçoamento de Pessoal de Nível Superior (Capes), for granting a master's degree scholarship (Finance Code 001) to Henrique da Costa Mendes Muniz.

\section{References}

CARABÚS, A.; SAINZ, R.D.; OLTJEN, J.W.; GISPERT, M.; FONT-I-FURNOLS, M. Growth of total fat and lean and of primal cuts is affected by the sex type. Animal, v.11, p.1321-1329, 2017. DOI: https://doi.org/10.1017/S1751731117000039.

CASAS, G.A.; RODRÍGUES, D.; TÉLLEZ, G.A. Propiedades matemáticas del modelo de Gompertz y su aplicación al crecimiento de los cerdos. Revista Colombiana de Ciencias Pecuarias, v.23, p.349-358, 2010.

COYNE, J.M.; BERRY, D.P.; MÄNTYSAARI, E.A.; JUGA, J.; MCHUGH, N. Comparison of fixed effects and mixed model growth functions in modelling and predicting live weight in pigs. Livestock Science, v.177, p.8-14, 2015. DOI: https://doi.org/10.1016/j.livsci.2015.03.031.

FERNANDES, F.A.; FERNANDES, T.J.; PEREIRA, A.A.; MEIRELLES, S.L.C.; COSTA, A.C. Growth curves of meat-producing mammals by von Bertalanffy's model. Pesquisa Agropecuária Brasileira, v.54, e01162, 2019. DOI: https://doi.org/10.1590/s1678-3921.pab2019.v54.01162.

FREITAS, A.R. de. Curvas de crescimento na produção animal. Revista Brasileira de Zootecnia, v.34, p.786-795, 2005. DOI: https://doi.org/10.1590/S1516-35982005000300010.

IGLESIAS, A.; CARRIL, J.A.; FERNÁNDEZ, M.; RODRÍGUEZ, I.M.; PÉREZ, C.; FRANCO, D.; LORENZO, J.M. Estudio de la curva de crecimiento de Richards en un cruce entre porcinos duroc X cerdo celta. Actas Iberoamericanas de Conservación Animal, v.4, p.196-198, 2014.

KEBREAB, E.; SCHULIN-ZEUTHEN, M.; LOPEZ, S.; SOLER, J.; DIAS, R.S.; DE LANGE, C.F.M.; FRANCE, J. Comparative evaluation of mathematical functions to describe growth and efficiency of phosphorus utilization in growing pigs. Journal of Animal Science, v.85, p.2498-2507, 2007. DOI: https://doi.org/10.2527/jas.2006-738.

KRESS, K.; MILLET, S.; LABUSSIÈRE, É; WEILER, U.; STEFANSKI, V. Sustainability of pork production with immunocastration in Europe. Sustainability, v.11, art.3335, 2019. DOI: https://doi.org/10.3390/su11123335.

KYRIAZAKIS, I.; WHITTEMORE, C.T. (Ed.). Whittemore's Science and Practice of Pig Production. $3^{\text {rd }}$ ed. Oxford: Blackwell, 2006. 705p. DOI: https://doi.org/10.1002/9780470995624.

LUO, J.; LEI, H.; SHEN, L.; YANG, R.; PU, Q.; ZHU, K.; LI, M.; TANG, G.; LI, X.; ZHANG, S.; ZHU, L. Estimation of growth 
curves and suitable slaughter weight of the Liangshan pig. AsianAustralasian Journal of Animal Sciences, v.28, p.1252-1258, 2015. DOI: https://doi.org/10.5713/ajas.15.0010.

MCKENZIE, J.; GOLDMAN, R.N. The student edition of minitab for windows manual. Belmont: Addison Wesley Longman, 2010.

NASCIMENTO, C.A.M.S.; RIBEIRO, M.N.; ROCHA, L.L.; LUCENA, L.R.R. Avaliação de curvas de crescimento em suínos. Archivos de Zootecnia, v.66, p.317-323, 2017. DOI: https://doi.org/10.21071/az.v66i255.2506.

NRC. NATIONAL RESEARCH COUNCIL. Nutrient requirements of swine. $11^{\text {th }}$ rev. ed. Washington, 2012. 400p.

REMUS, A.; HAUSCHILD, L.; POMAR, C. Simulated amino acid requirements of growing pigs differ between current factorial methods. Animal, v.14 p.725-730, 2020. DOI: https://doi.org/10.1017/S1751731119002660. 